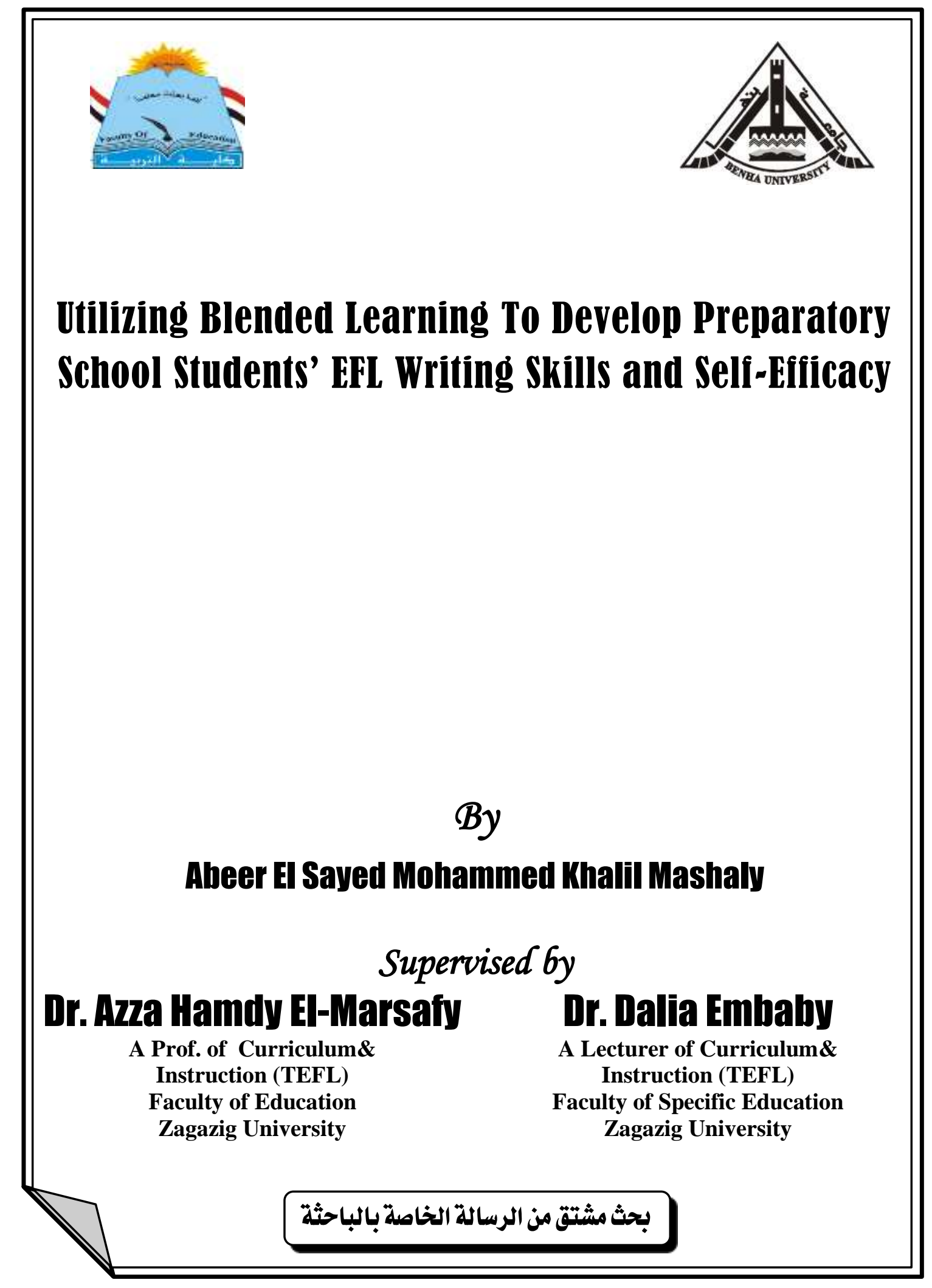




\title{
Utilizing Blended Learning To Develop Preparatory School Students' EFL Writing Skills and Self-Efficacy
}

\author{
By \\ Abeer EI Sayed Mohammed Khalil Mashaly \\ Supervised by \\ Dr. Azza Hamdy ElMarsafy \\ A Prof. of Curriculum\& \\ Instruction (TEFL) \\ Faculty of Education \\ Zagazig University

\section{Dr. Dalia Embaby} \\ A Lecturer of Curriculum\& \\ Instruction (TEFL) \\ Faculty of Specific Education \\ Zagazig University
}

\section{Introduction:}

Writing is one of the four skills that require special attention as it is a productive language process and plays a great role in conveying a written message accurately and effectively. Moreover, it is necessary in everyday life, in business and scholarly pursuits. It is a communicative skill to send, store and retrieve messages with the help of written symbols. It provides a permanent record of information, opinions, beliefs, feelings, arguments, explanation and theories. It allows learners to share communication not only with contemporaries, but also with future of past generations. In spite of the importance of writing, it still seems to be the most difficult language skill for language learners to acquire. It has been proved that EFL learners writing self-efficacy level has been linked to their poor performance in writing.

Williams,H. (2012) stated that self-efficacy is a key for success in writing. Alegro, (2006) defined self-efficacy as a belief that one can complete specific learning tasks effectively. The beliefs learners have about their ability to learn can be described as self-regulating which can regulate the ways in which the students approach the learning task as well as how they respond in classroom settings . 
Self-efficacy plays an important role in the development of writing competence. Writing self-efficacy means to students beliefs in their ability to perform written English tasks successfully. Such tasks include composition, correctly punctuating writing and creating grammatically correct samples of writing.

Blended learning is a natural evolution of e-learning towards a complete program of various multimedia applied in an ideal way to solve problems, taking into account the individual differences and achieving a distinguished teaching. It combines the advantages of face to face and elearning to satisfy individual differences (Bersin and Associate, 2003). The integration of blended learning in courses will naturally vary according to some factors such as :discipline, year level, student characteristics and needs, course or program learning objectives.

The goal of blended learning is to unite the best features of in-class teaching with the best features of online learning, to promote active, selfdirected learning opportunities for students (Garnham and Kaleta, 2002). Several studies like Tsou \& Wang Li, (2002), Al-Jarf, (2004), Chuo, (2007), and Al-Haq, (2010) have proved the effect of computer assisted programs or web-based programs on developing students' writing skills.

\section{Study Problem: $\square$}

The problem of the study could be identified in the inability of third year preparatory school students in EFL writing skills; quantity, purpose, genre, content, organization, grammar vocabulary\& mechanics and self-efficacy. Therefore this study aimed to develop these skills and self-efficacy through the use of blended learning

The present study attempted to answer the following main question: What is the effect of blended learning on developing the EFL writing skills and self-efficacy of third year preparatory school students? 
1- What are the necessary writing skills required for third year preparatory school students in learning English as a foreign language?

2- What is the students' current level in these skills ?

3- What is the writing self-efficacy level required for third year preparatory school students?

4- What is the relationship between EFL writing skills and self-efficacy?

5- What are the main characteristics of blended learning that can enhance the students' EFL writing skills and self-efficacy?

\section{Methodology}

\section{a-Study method:}

This study adopted the quasi-experimental method; i.e. pre/post writing test, pre/post self-efficacy scale and a sample of (exp. /control groups.)

\section{b-Study participants: $\square$}

The participants of the study ware chosen from third year preparatory stage students at sharkeya, namely Omar EL-Farouk formal school in zagazig city. They were 30 students: the control group $=15$ and the experimental group $=15$. The experimental group was taught through blended learning. The control group received the regular instruction.

\section{c-Study Instruments:}

\section{a-Writing:}

1- A questionnaire reviewing the writing skills required for the prep. stage students.

2- A writing test in the light of the approved writing skills.

3- A rubric for correcting the writing test.

\section{b-Self-efficacy:}

1- A questionnaire reviewing the self-efficacy dimensions required for the prep. stage students.

2- A self-efficacy scale in the light of the approved self-efficacy skills.

3- A rubric for correcting the self-efficacy scale. 


\section{Delimitations of the Study: $\square$}

1- The participants consisted of 30 third grade students (from Omar El-Farouk formal school), which were randomly distributed to two groups, experimental group and control one, 15 each.

2- Some EFL writing skills and self-efficacy that would be approved by the jury members.

3- Teaching EFL writing skills through implementing blended learning.

\section{Significance of the Study:}

The results of this study was hopefully expected to be useful to:

\section{a)Preparatory school students: $\square$}

Blended learning could be helpful to the prep students in developing their writing skills and self-efficacy. it might encourage students to overcome the difficulties they face in writing. It also could attract students' attention and drive their motivation in learning.

\section{b)Teachers of English: $\square$}

This study might provide teachers with practical procedures to develop their methods in teaching writing skills, self-efficacy and using e-learning in combination with face to face classroom instructions.

\section{c)Curriculum designers:}

This study might attract the attention of the curriculum designers to the value of implementing learning in the syllabus.

\section{Study Procedures: $\square$}

1- Reviewing relevant literature and previous studies related to blended learning, writing and self-efficacy.

2- Preparing a list of writing skills and a list of self-efficacy.

3- Designing a writing test, a writing self-efficacy scale and a blended learning model.

4- Selecting the study participants from 3rd year preparatory school students and determining the experimental and the control groups. 
5- Pre administering the writing test and the self-efficacy scale to both groups.

6- Teaching the experimental group using the blended learning model.

7- Post administering the writing test and the self-efficacy scale to both groups.

8- Comparing the pre to the post results of both administrations of both instruments.

9- Using a suitable statistical method to measure the effect of the blended learning model on developing the identified writing skills and self-efficacy ones.

10- Discussing the results.

11- Providing conclusion, recommendations, suggestions for further research and study implications.

\section{Study Hypotheses: $\square$}

This part deals with testing the validity of the study hypotheses.

\section{a)Hypothesis One:}

It was hypothesized that "There would be a statistically significant difference between the mean of scores of the experimental group in the pre/ post writing skills test in favor of the post administration". To determine the relative extent of change fostered by the implementation of the blended learning from the pre to the post administration for the experimental group in the writing skills test, t-test for paired samples was used. See table 1.

Table (1): t-values for the Differences between the Pre and Post

Writing Skills Test results of the experimental group

\begin{tabular}{|c|c|c|c|c|c|c|c|c|}
\hline Group & N & Mean & S.D & t-value & Df & Significance & $\square^{\square}$ & D \\
\hline \hline Post & 15 & 40.33 & 5.26 & $8.94^{*}$ & 14 & 0.000 & 0.85 & 4.78 \\
\cline { 1 - 3 } Pre & 15 & 24.60 & 9.65 & & & & & \\
\hline
\end{tabular}

$\mathrm{P}<0.05$ (Significant) 
Table 1 illustrates that there was a statistically significant difference at 0.05 level of significance in the writing skills test between the mean of scores of the experimental group in the pre-post administrations of the test, in favor of the post- administration scores. tvalue being 8.94. This value is significant at 0.05 level in favor of the post administration. Moreover, the estimated effect size value is (4.78). These results provide enough evidence to support the first hypothesis.

\section{b)Hypothesis Two: $\square$}

It was hypothesized that "There would be a statistically significant difference between the mean of scores of the experimental and control groups in the post administration of the writing skills test, in favor of the experimental group . t-test for independent samples was used to validate this hypothesis.

Table (2): t-values for the Differences between the Experimental

Group and The Control Group on Writing Skills posttest

\begin{tabular}{|l|c|c|c|c|c|c|c|c|}
\hline Group & N & Mean & S.D & t-value & Df & Significance & $\square^{\square}$ & D \\
\hline \hline Control & 15 & 36.13 & 2.387 & $2.82^{*}$ & 28 & 0.01 & 0.22 & 1.06 \\
\cline { 1 - 3 } Exper. & 15 & 40.33 & 5.26 & & & & & \\
\hline \hline
\end{tabular}

$\mathrm{P}<0.05$ (Significant)

Table 2 illustrates that there was a statistically significant difference at 0.05 level of significance in the writing skills test between the mean of scores of the experimental and control groups in the post administration of writing skills test, in favor of the experimental group, $t$ value being (2.82). This value is significant at 0.05 level in favor of post administration of the experimental group. Therefore this provides enough evidence to support hypothesis two. Moreover, the estimated effect size value (1.06) indicates that significance.

The t-values proved that the differences in participants' writing performance were significant with $95 \%$ level of trust/ confidence. The above results adequately supported the second hypothesis. 


\section{c) Hypothesis three:}

It was hypothesized that "There would be a statistically significant difference between the mean of scores of the experimental group in the writing self-efficacy pre/ post scale administrations, in favor of the post administration". t-test for paired samples was used to validate this hypothesis. See table three.

Table (3): t-values for the Differences between the Pre and Post administrations of the writing Self-efficacy scale of the experimental group.

\begin{tabular}{|c|c|c|c|c|c|c|c|c|}
\hline Group & N & Mean & S.D & t-value & Df & Significance & $\square^{\square}$ & D \\
\hline \hline Post & 15 & 63.07 & 1.71 & $6.79^{*}$ & 14 & 0.000 & 0.77 & 3.63 \\
\cline { 1 - 3 } Pre & 15 & 48.27 & 9.57 & & & & & \\
\hline
\end{tabular}

$\mathrm{P}<0.05$ (Significant)

Table 3 illustrates that there was a statistically significant difference at 0.05 level of significance in the writing self-efficacy scale between the mean of scores of the experimental group in the pre-post administrations of the scale, in favor of the post- administration, t-value for writing self-efficacy scale being (6.79). This value is significant at 0.05 level. Moreover, the estimated effect size value (3.63) indicates that significance. This result provides enough evidence to support the third hypothesis.

\section{c) Hypothesis four:}

It was hypothesized that "There would be a statistically significant difference between the mean of scores of the experimental and control groups in the post administration of the writing self-efficacy scale, in favor of the experimental group". t-test for independent samples was used to validate this hypothesis. 
Table (4): t-values for the Differences between the Experimental Group and The Control Group on the writing Self-efficacy scale post administration

\begin{tabular}{|c|c|c|c|c|c|c|c|c|}
\hline Group & $\mathbf{N}$ & Mean & S.D & t-value & Df & Significance & $\square^{\square}$ & D \\
\hline \hline Control & 15 & 58.07 & 1.58 & \multirow{2}{*}{$8.32^{*}$} & 28 & 0.000 & 0.71 & 3.15 \\
\cline { 1 - 5 } Exper. & 15 & 63.07 & $\begin{array}{c}1.71 \\
0\end{array}$ & & & & & \\
\hline
\end{tabular}

$\mathrm{P}<0.05$ (Significant)

Table 4 illustrates that there was a statistically significant difference at 0.05 level of significance in writing self-efficacy scale between the mean of scores of the experimental and control groups in the post administration of the writing self-efficacy, in favor of the experimental group, $t$-value for writing self-efficacy scale being (8.32). This value is significant at 0.05 level. Therefore, this provides enough evidence to support hypothesis four. Moreover, the estimated effect size value is (3.15). The t-test results proved that the differences in participants' writing self-efficacy were significant with 95\% level of trust/ confidence. The above results adequately supported the fourth hypothesis.

\section{Discussion and interpretation of Results $\square$}

\section{a.Results of the study:}

The results of the current study showed that the experimental group outperformed the control one on the writing posttest as a whole and its sub-skills. Hence, the significant differences are due to exposing this group to the blended learning model. These results also indicated the improvement of the experimental group participants' self-efficacy if compared to the control group participants.

These results also revealed that there is a statistically significant differences between the mean of scores of the study participants in writing self-efficacy pre-post assessment, in favor of the post assessment. There is also a statistically significant difference between 
the mean of scores of the experimental and control groups in the post administration of the writing self-efficacy scale in favor of the experimental group, Thus, the study participants' level of writing selfefficacy developed. So, blended learning had a positive effect on developing participants writing self-efficacy.

\section{b. Interpretation of the results:}

Results of the current study are discussed with reference to the hypotheses validation and the relevant literature.

The primary purpose of this study was to develop EFL writing skills and writing self-efficacy among third year prep. students enrolled using blended learning model which included a variety of tasks and activities for helping participants enhance their EFL writing skills and writing self-efficacy. Regarding the effect of blended learning model in developing their writing skills and writing self-efficacy, the obtained results proved significant differences between the pre and the post administrations of the writing skills test and writing self-efficacy scale to the experimental group favoring the post results. So, the blended learning model proved to be statistically and educationally significant in developing participants writing skills and writing self-efficacy.

After the administration of the blended learning model, the participants achieved progress and development in writing skills, which could be attributed to several factors that stem from the nature of the blended model which has been based on the notion that teacher and students work together through the activities incorporated in the model such as brainstorming, discussing and questioning in the three stage; face to face stage, online stage and the evaluation stage.

The justification of the results above could be that blended learning exposed participants to a variety of vocabulary; structure and 
language style; related more closely to the participants' needs in the real world ; helped in developing participants' writing skills (Martinez, 2002; Xerri, 2012). This result is logic as the participants moved from their limited learning environment (using only textbooks) to another one connecting them with the language as it is used in the real world by native speakers. Blended learning activities (a) increased their knowledge of vocabulary items needed in real situations, (b) introduced them to how language is used in the real world, (c) improved their language proficiency as well as writing performance, (d) were interesting, (e)fulfilled their needs, and (f) enabled them to enhance their writing styles.

Results of the present study lend support to those of Watson, (2009); Ireland, (2008); Krause, (2008); Kose, (2010); Dziuban, (2011); Yam and Rossini, (2011); Fainholc and Scagnoli, (2009); Woodall, (2010) ; and Rikkinen and Virtanen (2009). These studies assured that there is a positive relationship between using blended learning in teaching writing skills.

The results of the study can be also interpreted by several factors. It seems that the participants believed in their ability to perform different writing tasks or acquire different writing skills, they developed their beliefs in their ability to write. This is because writing self-efficacy has one common source: mastery experiences. The personal experiences these participants had played a significant role in their belief that they can write. This factor is the most influential source of self-efficacy and has the greatest impact on the participants' writing skills (Bandura, 2000; Pajares, 2002; Reese, 2009; Taylor, 2008; Woolford-Singh, 2004; Zimmer, 1995).

\section{Conclusion:}

Based on the results shown through the statistical analysis of data and discussion, it can be concluded that blended learning proved to be effective in developing the EFL writing skills, sub-skills and self- 
efficacy for third year preparatory school students. The enormous possibilities that blended learning provided proved to be effective in providing the students with a positive self-esteem, responsibility for learning and more positive relationships which helped to develop their writing and self-efficacy. Moreover, the use of online learning provided an opportunity for shy students to overcome their shyness and participate effectively. The keyboard and screen proved to be less intimidating than humans, and shy students who refused to share in the class seemed to have fingers flying across the keyboard in the online phase. Students who are reluctant to write were able to improve their skills and they felt free when sharing via the facebook group. This helped them write more sentences, communicate the purpose of writing to the reader and generate ideas related to the topic of interest, provide supporting details, that develop the main idea, end the topic in a good and relevant conclusion, write the proper form of paragraphs, letters and emails, use logical transitions for ensuring smooth flow of ideas and logical sequence of sentences. This also helped them to use grammatical rules correctly and use correct word spelling .

Blended learning connected the students with the real life situations through the online learning and thus, made learning more realistic and interesting to them. As dealing with the technological possibilities (facebook, email, etc.) is actually a part of their everyday life, the students could practice the skills without the fear of the number of repetition needed to master these skills. Thus, the learners' anxiety and embarrassment were reduced. This helped the students correct their errors without the threat of face-to-face confrontation.

Also the improvement can be attributed to the fact that blended learning provided the students with a relaxing positive teaching/ learning environment and connected the students with their own personal life experiences, and thus, made learning more realistic to them. 
Whereas, the control group received regular instruction just in the classroom environment which made them feel anxious in their learning. The control group encountered some problems, i.e. hesitation in front of their classmates and being shy to talk. Thus, the learners' confidence had to be maintained within a non-threating environment. Also, the participants in the control group didn't have enough time to practice more activities. Most of them were reluctant to share. They didn't have the enthusiasm to practice in front of their classmates. Thus, the absence of any progress in the control group may be due to the absence of blended learning

\section{Recommendations:}

1- Blended learning should include a variety of activities to enable the students to practice writing in an interactive way.

2- EFL teachers should promote students' interest /attitude toward English language learning by using blended learning and other means of technology like facebook, e-mails, etc.

3- Students should learn how to use sentences in meaningful situations to develop their writing and self-efficacy.

4- Blended learning should provide a positive and unthreatening learning environment of interaction any which participants can be trained to produce extended written discourse and consider different aspects while writing such as purpose, genre, content, organization, grammar, vocabulary and mechanics.

5- Teachers should offer strategies that help build confidence and self-efficacy in their writing and provide students with opportunities to participate in various writing activities, and feel that their writing had value. 
6- Writing should be given a greater importance and emphasis as an act of communication. Students should be provided with opportunities to share with their teachers and discuss their writing with teachers and beers.

7- EFL teachers need to be provided with training to explore the usefulness of using blended learning to master its integration in their classrooms and learn about how to design blended models to enhance their students' learning by adding a variety of activities and avoid monotony of teaching.

8- Blended learning activities should be integrated within the learning curriculum, relating them to the goals and objectives of the course.

9- EFL teachers should emphasize the development of the students' writing skills and writing self-efficacy in the early educational stages to develop them in the following ones.

10- It is also recommended that teachers get trained to teaching writing as a process not as a product and adopting process writing in teaching writing skills as this approach offers students an outstanding opportunity to learn how to write and make writing easier and more interesting .

11- Students should be offered enough opportunities to practice writing, paying attention to the fact that writing is a developmental skill that improves gradually.

12- Students should get continuous feedback on their writing skills without the threat of face-to-face confrontation. This can be achieved through blended learning other technical trends. 
13- Teachers should change their role from examiners who evaluate students' writing to a guide, facilitator, consultant and an organizer to the student ideas, who help students improve their writing skills and writing self-efficacy. Since then, the evaluation process will not be a frightened experience that causes them to avoid writing.

14- More attention should be paid to the psychological factors such as self-efficacy and self-beliefs that affect students' skills and achievement.

\section{Suggestions for further research:}

1- Investigating the relationship between blended learning and other writing skills, i.e. critical and creative writing at various educational stages.

2- Investigating the relationship of blended learning and other language skills, e.g., reading, speaking and listening.

3- Designing similar models based on blended learning for students at different stages (secondary and university).

4- Conducting more research using this model with other class categories in other courses of study.

5- Investigating the relationship of this blended learning model and other variables such as reading awareness, reading comprehension, reading interests and students attitudes towards studying English.

6- Investigating the relationship of other instructional strategies and students' writing skills and writing self-efficacy.

7- Designing a course for training pre-services and in-services teachers to how to adopt the blended learning model. 


\section{References}

- Al-Haq A., F. (2010): The effect of a web-based writing instructional EFL program on enhancing the performance of Jordanian secondary students. The JALT CALL Journal 6(3) : $189-218$.

- Aliegro j.c., (2006): The effect of self-assessment on the selfefficacy of students studying Spanish as a foreign language (Published Ph.D Dissertation, Graduate faculty of Education,University of Pittsburg, Pennsylvania).

- Al-Jarf, R. (2007): Impact ofBlended Learning on EFL College Readers. IADIS International Conference e-Learning 2007 Lisbon. Portugal. July 6-8.

- Bersin and Associates (2003): Blended Learning: What Works? Available at: $\underline{w w w} \cdot$ bersin.com

- Chuo, T.W.I. (2007): The Effect of the Web Quest Writing Instruction on EFL Learners' Writing Performance, Writing Apprehension, and Perception. TESL-EJ-Teaching English as a Second or Foreign Language, 11, (3), 1-27.

- Dziuban, C.et al, (2011): A Time-based Blended Learning Model. On the Horizon. Vol. 19. Iss:3.

- Fainholc, B., \& Scagnoli, N. I. (2009): Case Study : Blended Learning Through Interuniveristy Collaborative Interaction. Presented at the Annual Conference on Distance Teaching \& Learning. Madison, WI. 
- Garnham, C.\& Kaleta, R. (2002): Introduction To Hybrid courses. Teaching with Technology Today. Vol.8 (6). Available at: http:// www.uwsa.edu/ttt/articles/garnham.htm

- Garrison,D. \& Vaughan, N.(2008): Blended Learning in Higher Education. San Francisco: Jossey-Bass.

- Ireland, J. (2008): Blended Learning in Intellectual Property: The Best of Both Worlds. Legal Education Review, Vol.18, No.1/2,2008: 139-161.Available at:

- http://search.informit.com.au/documentSummary;dn=77062909263 5129;res=IELHSS >ISSN:1033-2839.[cited 01 Dec 12].. rev. 139.

- Kose, U. (2010): A Blended Learning Model Support with web 2.0 Technologies. Science Procedia Social and Behavioral Sciences. Vol.2(2). (2010) 2794-2802. Available at:

- http://www.academia.edu/521378/A blended learning model supported_with_Web_2.0 technologies

- Krause, K.(2008): Blended learning Strategy. Griffith University. Document number 2008/0016252.January 2008. Available at: http://www.griffith.edu.au/about-griffith/planspublications/pdf/blended-learning-strategy-january-2008-apriledit.pdf

- Martinez, A.G. (2002): Authentic materials; An overview. Free resources for teachers and students of English, Karen's Linguistics Issues, 1-7.

- Pajares, F.(2002): Gender and Perceived Self-efficacy in Selfregulated learning. Theory into practice, 41, 116-125. 
- Reese, J.A. (2009): The Effects of a Multi-linguistic Diagnostic Spelling Intervention on the Writing Achievement and Writing Self-perception Beliefs of Secondary Students: Phonology Orthography, and Morphology. Unpublished Doctoral Dissertation, University of Southern California, USA.

- Rikknen, J. \& Virtanen, V.(2009): Blended Learning In Biodiversity Teaching In: Joutsenvirta, T \& Myyry, L. (eds.) Blended Learning in Finland. Publication of the Faculty of Social Sciences, University of Helsinki. Available at: http://www.helsinki.fi/valtiotieteellinen/julkaisut/blended_learni ng_Finland.pdf

- Taylor, M.S. (2008): Exploring the relationship between Teacher Efficacy and Beliefs and Orientations towards Writing. Unpublished Doctoral Dissertation. Walden University, USA.

- Tsou, W. L., Wang, W. H., \& Li, H. Y. (2002): How computers facilitate English foreign language learners acquire English abstract words. Computers \& Education, 39(4): 415-428.

- Williams, H.M. (2012): Third Grade Students' Writing Attitude, Self-Efficacy Beliefs, and Achievement. Unpublished Master Thesis. Faculty of the Graduate School. University of Maryland, College Park.

- Waston, J.(2009): Blended Learning: The Convergence of Online and Face-to-face Education, Published by the North American Council For Online Learning (NACOL). Available at: http://www.inacol.org/org/research/promisingpractices/NACOL PP-BlendedLearning-Ir.pdf 
- Woodall, D.(2010): Blended Learning Strategies: Selecting The Best Instructional Method. Available at:

- http://www.trainingmagnetwork.com/files/post_attaachment/350 8/7645/1292/Blended_Learning_Strategies_WP.pdf

- Woolford-Singh, A. (2004): An Examination of Relationships Reading and Writing Self-Efficacy Beliefs, Standardized Placement Test Scores, and Diverse Community College Students' Perceptions of Those relationships. Unpublished Doctoral Dissertation. Old Dominion, USA.

- Zimmer, B. (1995): The empathy templates: A Way To Support Collaborative Learning. In F. Lockwood (Ed.), Open and Distance Learning Today. London: Routledge.

- Yam, S.\&Rossini, P. (2011): Online learning and blended learning: which is more effective? $17^{\text {th }}$ pacific Rim Real Estate Society Conference. 16-19 January 2011-Gold Coast, Australia. 